Electronic Supplemental Information for

\title{
A Terminal Rh Methylidene from Activation of $\mathrm{CH}_{2} \mathbf{C l}_{2}$
}

Travis J. Morrow, Jordan Gipper, William E. Christman,

Navamoney Arulsamy, Elliott B. Hulley*

Department of Chemistry, University of Wyoming

Laramie, WY 82070, USA

*Correspondence to: ehulley@uwyo.edu

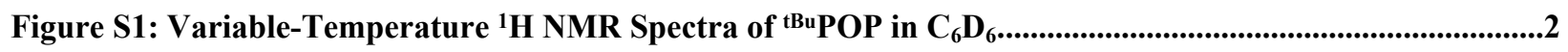

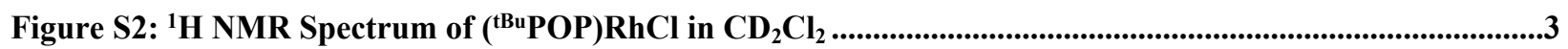

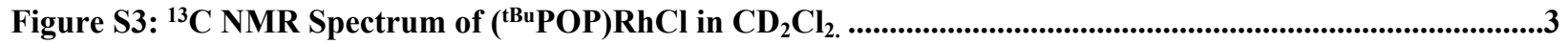

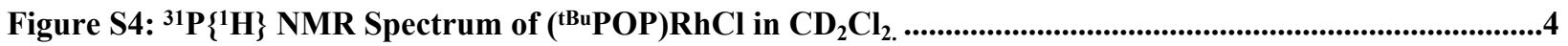

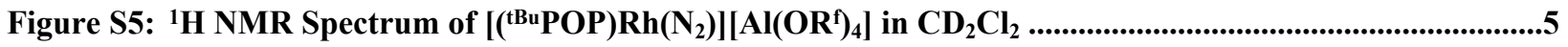

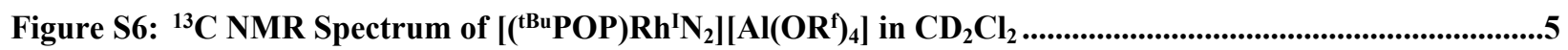

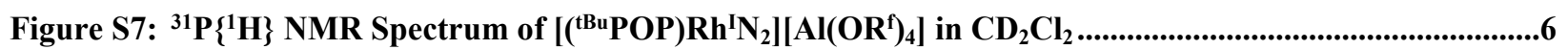

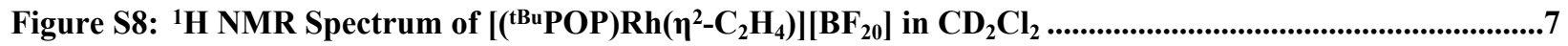

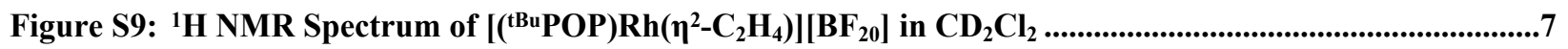

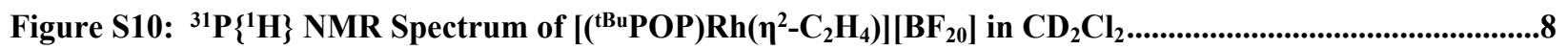

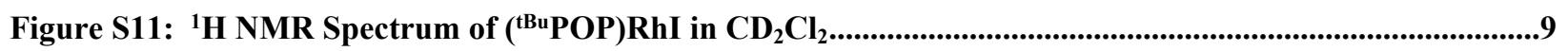

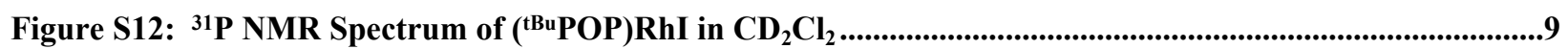

Figure S13: Generation of [(POP)RhI] $]^{+}$and [(POP)RhCH $\left.{ }_{2}\right]^{+}$from Redox Cascade Activation of $\mathrm{CH}_{2} \mathrm{Cl}_{2}$ by

(POP)RhI. ...........................................................................................................................................................10

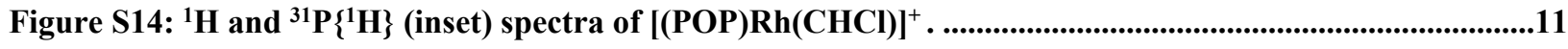

X-ray Crystallography..................................................................................................................................................12

Table S1. Crystallographic data for $[(\mathrm{POP}) \mathrm{RhCl}]_{2}\left(\mu^{2}-\mathrm{K}\left[\mathrm{B}\left(\mathrm{C}_{6} \mathrm{~F}_{5}\right)_{4}\right]_{2},[(\mathrm{POP}) \mathrm{RhCl}]_{3}\left[\mathrm{~B}\left(\mathrm{C}_{6} \mathrm{~F}_{5}\right)_{4}\right]_{2}\right.$, and

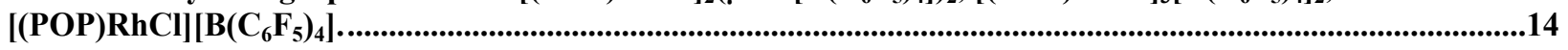

Figure S14. View of crystallographically independent molecules of (POP)RhCl (top) and [(POP)RhCl ${ }^{+}$

(bottom)........................................................................................................................................................15

Table S2. Comparison of Calculated and Experimental Bond Length and Angles for (POP)RhCl and [(POP)RhCl $]^{+}$.................................................................................................................................................16

Table S3. Calculated $\Delta \mathbf{G}_{\text {reaction }}$ and Formal Redox Potentials for Proposed Intermediates.................................17

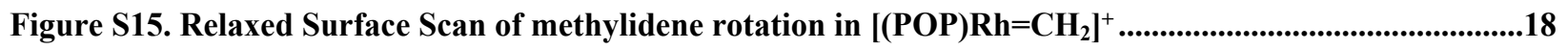

Table S4. Pressure Corrected Boiling Points for Selected Solvents and Reagents .....................................................19

References...............................................................................................................................................................................20 
Figure S1: Variable-Temperature ${ }^{1} \mathrm{H}$ NMR Spectra of ${ }^{\mathrm{tBu} P O P}$ in $\mathrm{C}_{6} \mathrm{D}_{6}$

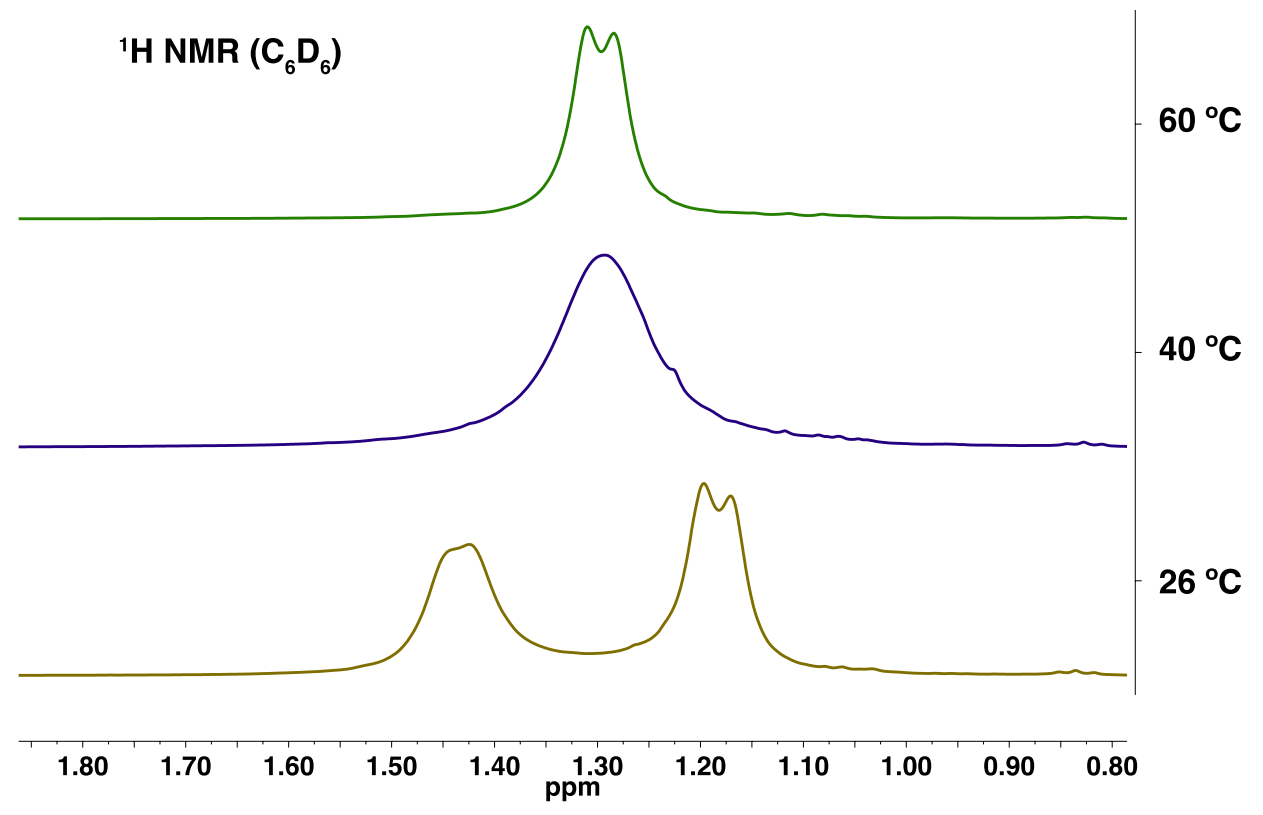


Figure S2: ${ }^{1} \mathrm{H}$ NMR Spectrum of $\left({ }^{\mathrm{tBu} P O P}\right) \mathrm{RhCl}$ in $\mathrm{CD}_{\mathbf{2}} \mathrm{Cl}_{2}$

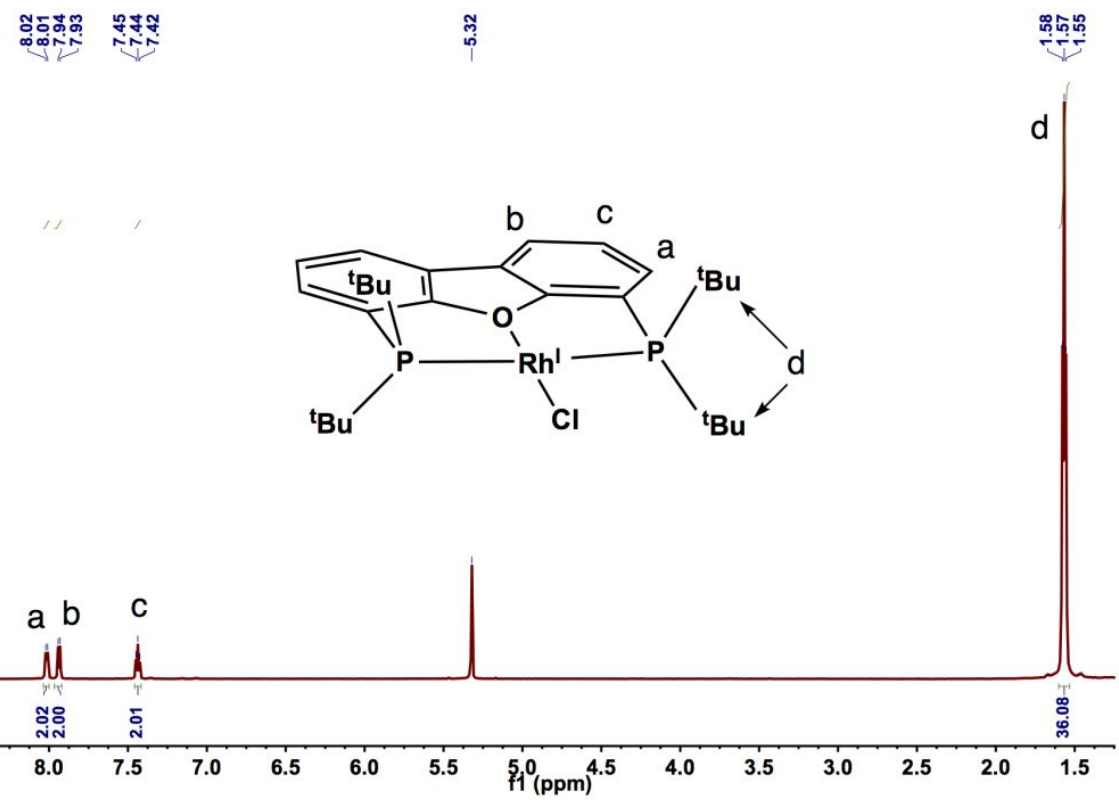

Figure S3: ${ }^{13} \mathrm{C}$ NMR Spectrum of $\left({ }^{\mathrm{tBu} P O P}\right) \mathrm{RhCl}$ in $\mathrm{CD}_{\mathbf{2}} \mathrm{Cl}_{2}$.
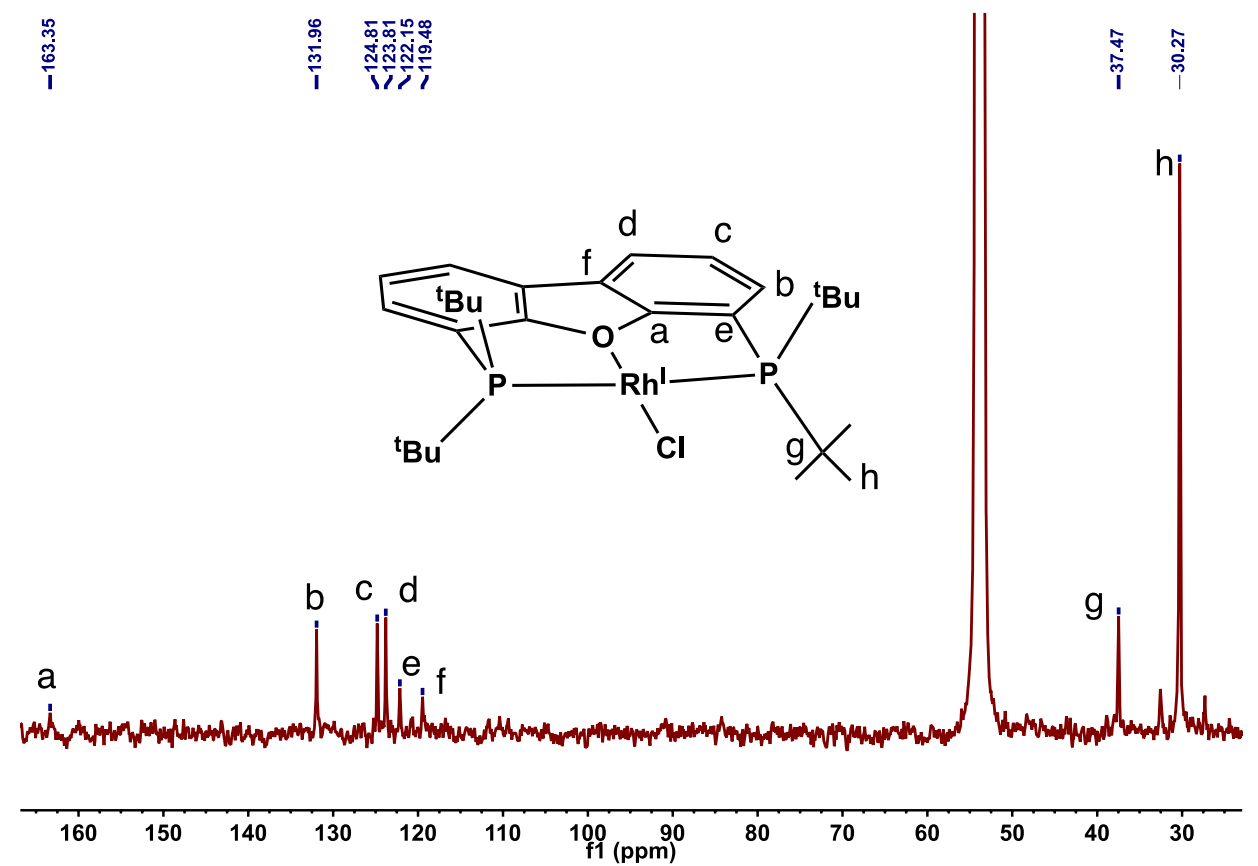
Figure S4: ${ }^{31} \mathrm{P}\left\{{ }^{1} \mathrm{H}\right\}$ NMR Spectrum of ( $\left.{ }^{\mathrm{tBu}} \mathrm{POP}\right) \mathrm{RhCl}$ in $\mathrm{CD}_{2} \mathrm{Cl}_{2}$.

$\underset{\substack{0 \\ 0}}{\substack{0 \\ i}}$

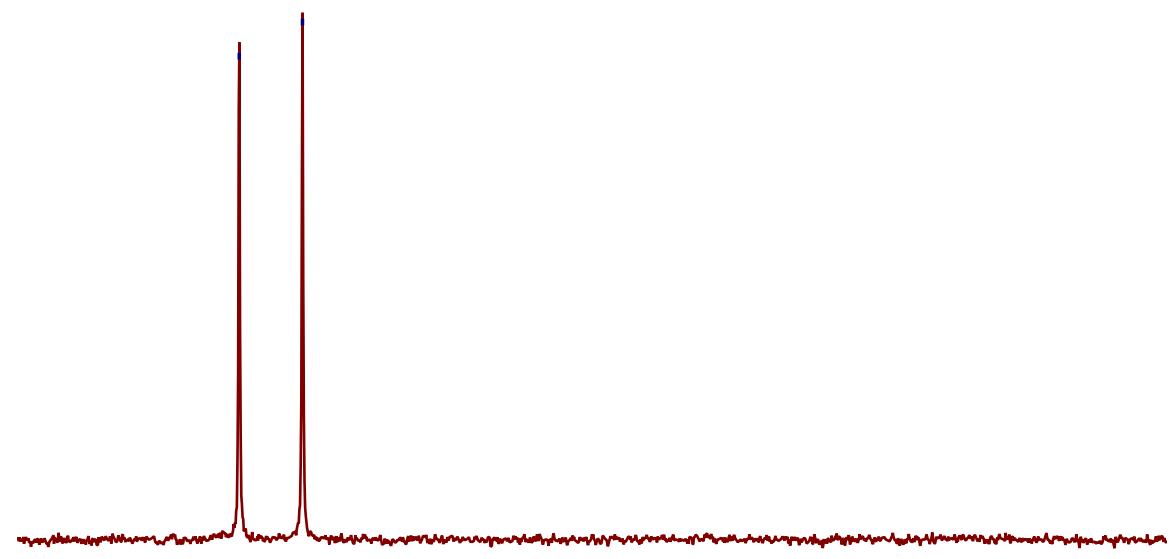

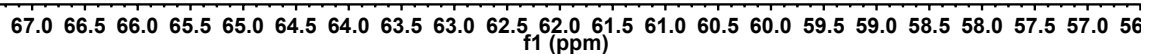


Figure S5: ${ }^{1} \mathrm{H}$ NMR Spectrum of $\left[\left({ }^{(B u P O P}\right) R h\left(\mathrm{~N}_{2}\right)\right]\left[\mathrm{Al}\left(\mathrm{OR}^{\mathrm{f}}\right)_{4}\right]$ in $\mathrm{CD}_{2} \mathrm{Cl}_{2}$

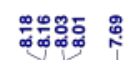

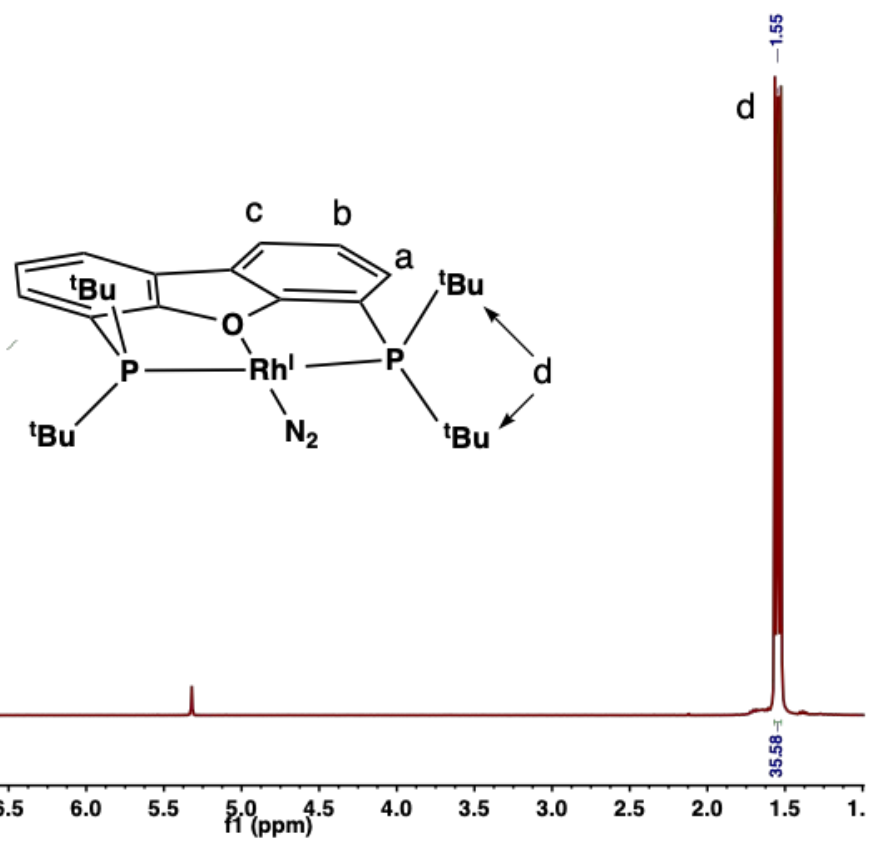

Figure S6: ${ }^{13} \mathrm{C}$ NMR Spectrum of $\left[\left({ }^{(\mathrm{Bu} P O P}\right) \mathrm{Rh}^{\mathrm{I}} \mathrm{N}_{2}\right]\left[\mathrm{Al}\left(\mathrm{OR}^{\mathrm{f}}\right)_{4}\right]$ in $\mathrm{CD}_{2} \mathrm{Cl}_{2}$
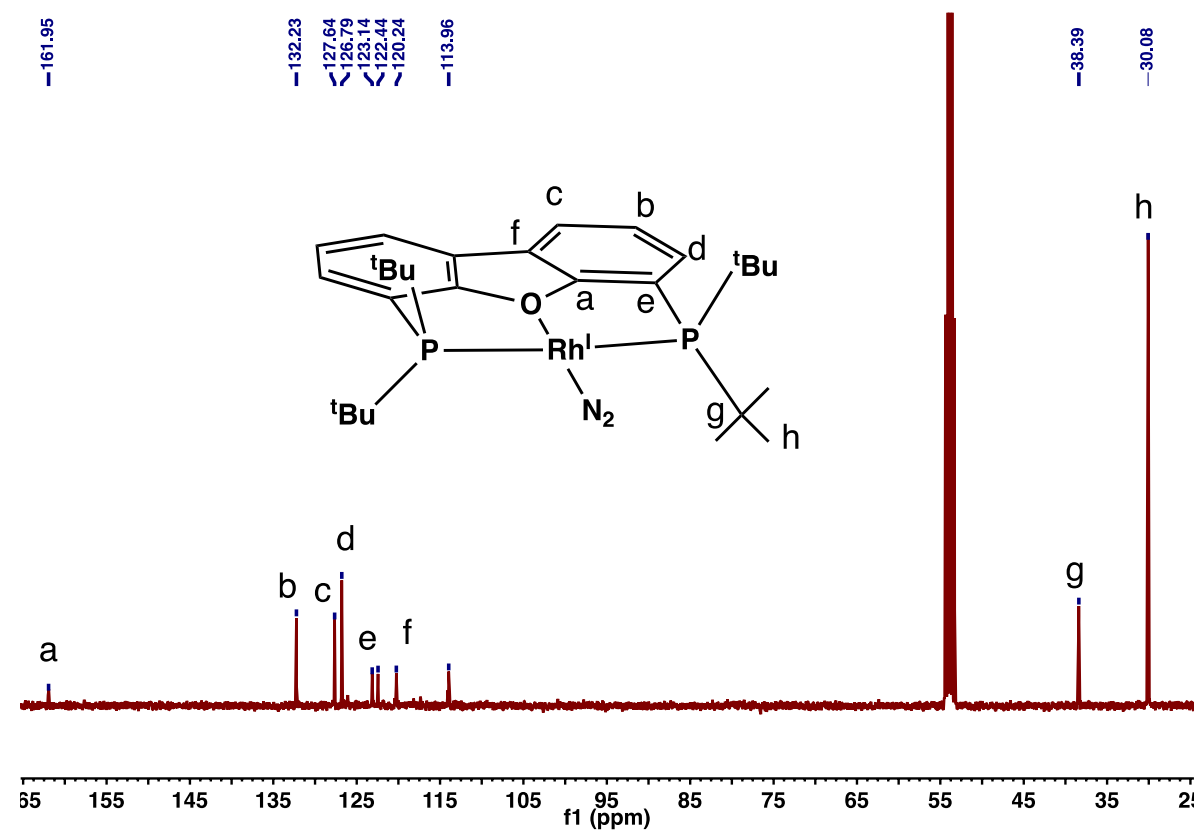
Figure S7: ${ }^{31} \mathrm{P}\left\{{ }^{1} \mathrm{H}\right\}$ NMR Spectrum of $\left[\left({ }^{\mathrm{tBu} P O P}\right) \mathrm{Rh}^{\mathrm{I}} \mathrm{N}_{2}\right]\left[\mathrm{Al}\left(\mathrm{OR}^{\mathrm{f}}\right)_{4}\right]$ in $\mathrm{CD}_{2} \mathrm{Cl}_{2}$

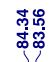

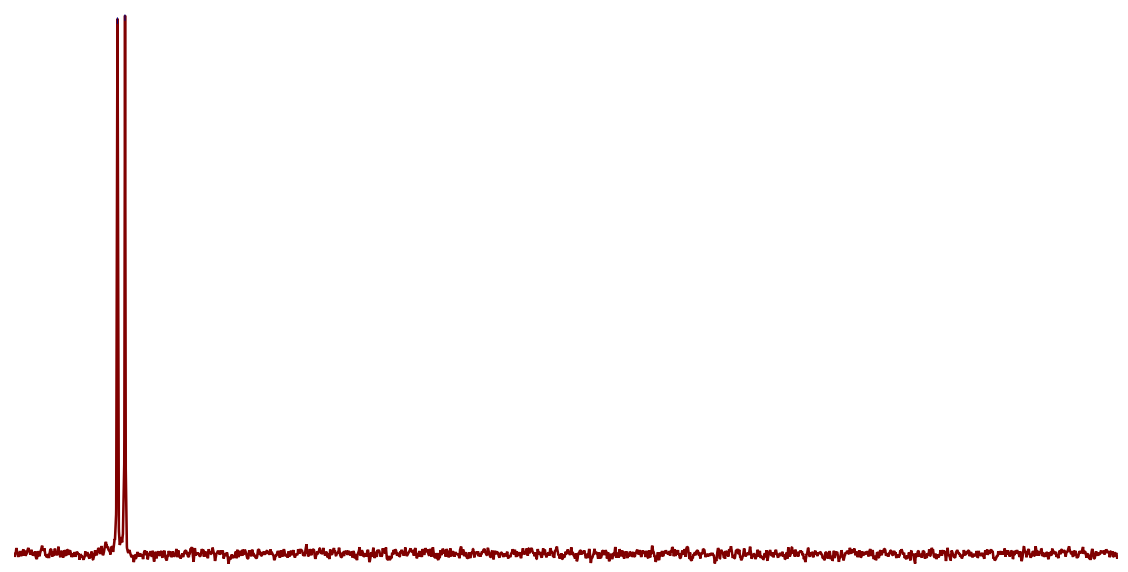

$\begin{array}{llllllllllllllllllllll}90 & 85 & 80 & 75 & 70 & 65 & 60 & 55 & 50 & 45 & \begin{array}{c}40 \\ \mathrm{f} 1\end{array}\left(\begin{array}{lllllll}35 \\ (\mathrm{ppm})\end{array}\right. & 30 & 25 & 20 & 15 & 10 & 5 & 0 & -5 & -10 & -15\end{array}$ 
Figure S8: ${ }^{1} \mathrm{H}$ NMR Spectrum of $\left[\left({ }^{\mathrm{Bu}} \mathrm{POP}\right) \mathrm{Rh}\left(\eta^{2}-\mathrm{C}_{2} \mathrm{H}_{4}\right)\right]\left[\mathrm{BF}_{20}\right]$ in $\mathrm{CD}_{2} \mathrm{Cl}_{2}$
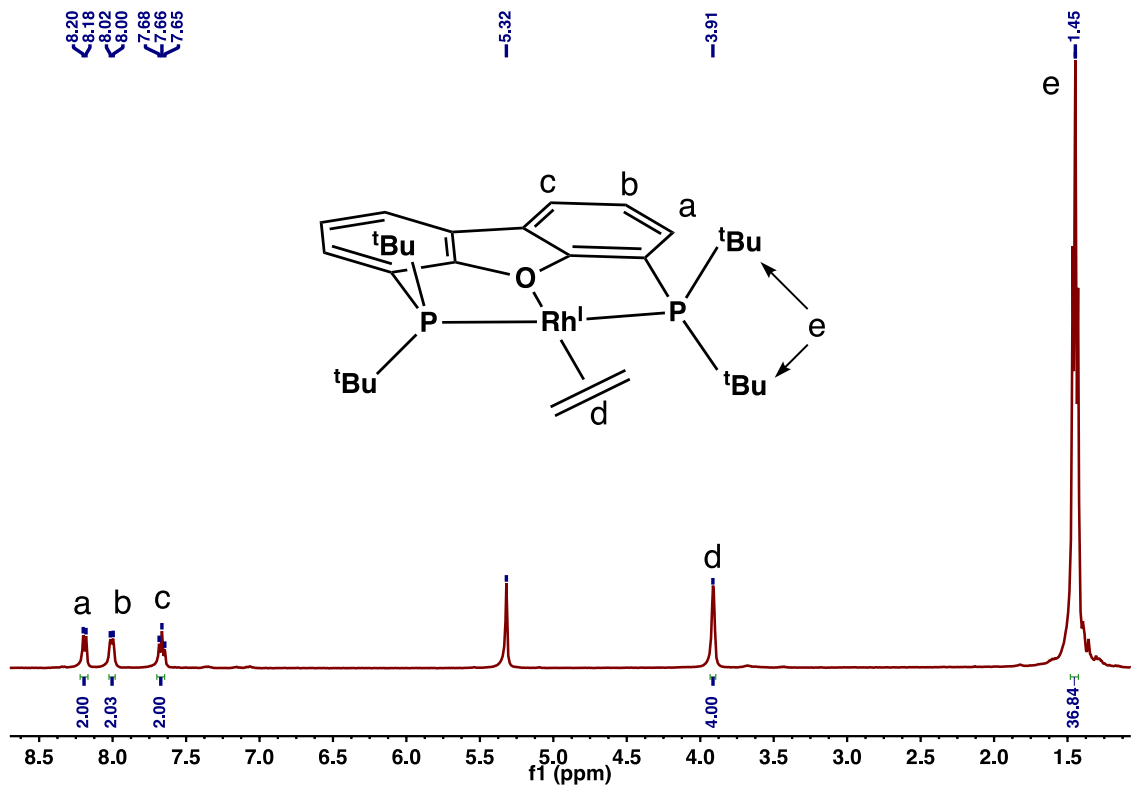

Figure S9: ${ }^{1} \mathrm{H}$ NMR Spectrum of $\left[\left({ }^{\mathrm{Bu} u} \mathrm{POP}\right) \mathrm{Rh}\left(\eta^{2}-\mathrm{C}_{2} \mathrm{H}_{4}\right)\right]\left[\mathrm{BF}_{20}\right]$ in $\mathrm{CD}_{2} \mathrm{Cl}_{2}$

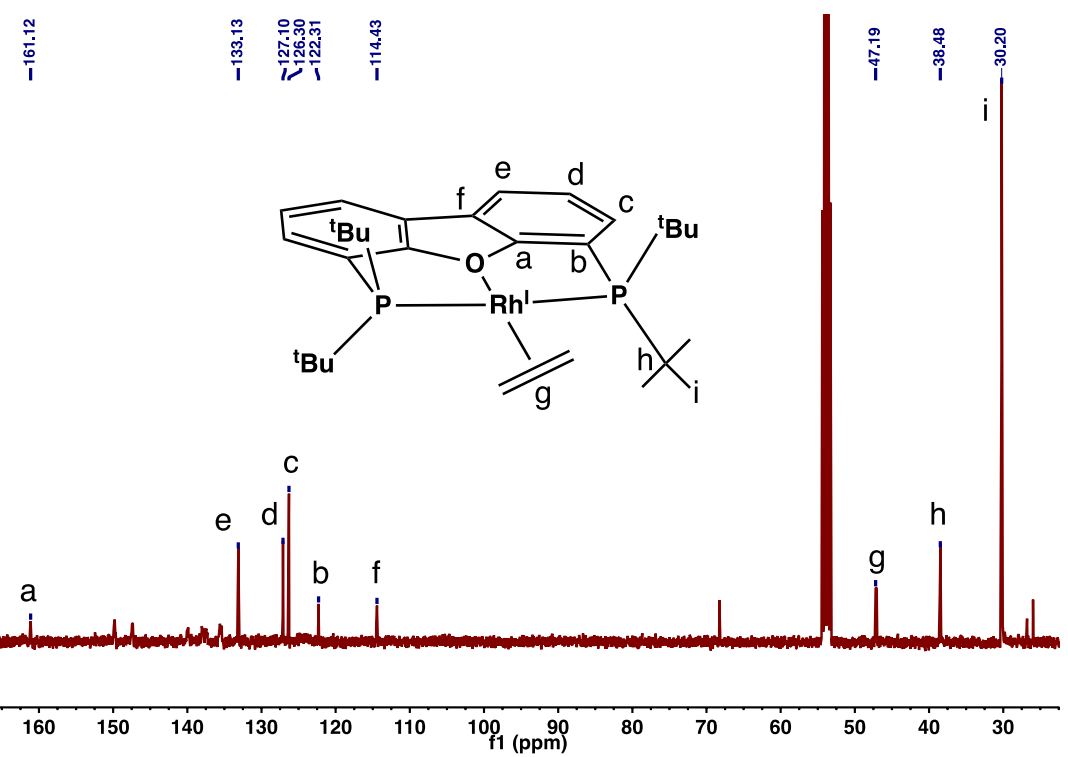

Assignments were made via comparison with known compounds; non-assigned signals are from residual solvents present in the bulk NMR solvent. 
Figure S10: ${ }^{31} \mathrm{P}\left\{{ }^{1} \mathrm{H}\right\}$ NMR Spectrum of $\left[\left({ }^{\mathrm{tBu} P O P}\right) \mathrm{Rh}\left(\eta^{2}-\mathrm{C}_{2} \mathrm{H}_{4}\right)\right]\left[\mathrm{BF}_{20}\right]$ in $\mathrm{CD}_{2} \mathrm{Cl}_{2}$

$\begin{array}{ll}\stackrel{0}{0} & \stackrel{0}{0} \\ \stackrel{0}{0} & 1\end{array}$

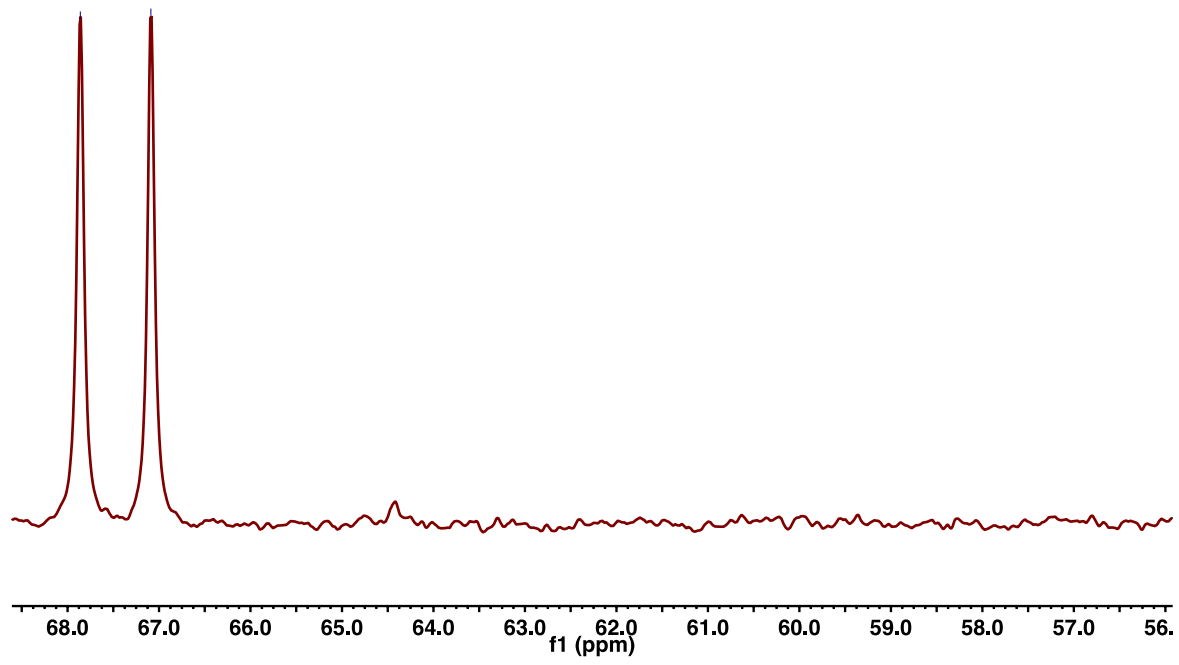


Figure S11: ${ }^{1} \mathrm{H}$ NMR Spectrum of ( $\left.{ }^{\mathrm{tBu} P O P}\right) \mathrm{RhI}$ in $\mathrm{CD}_{\mathbf{2}} \mathrm{Cl}_{\mathbf{2}}$

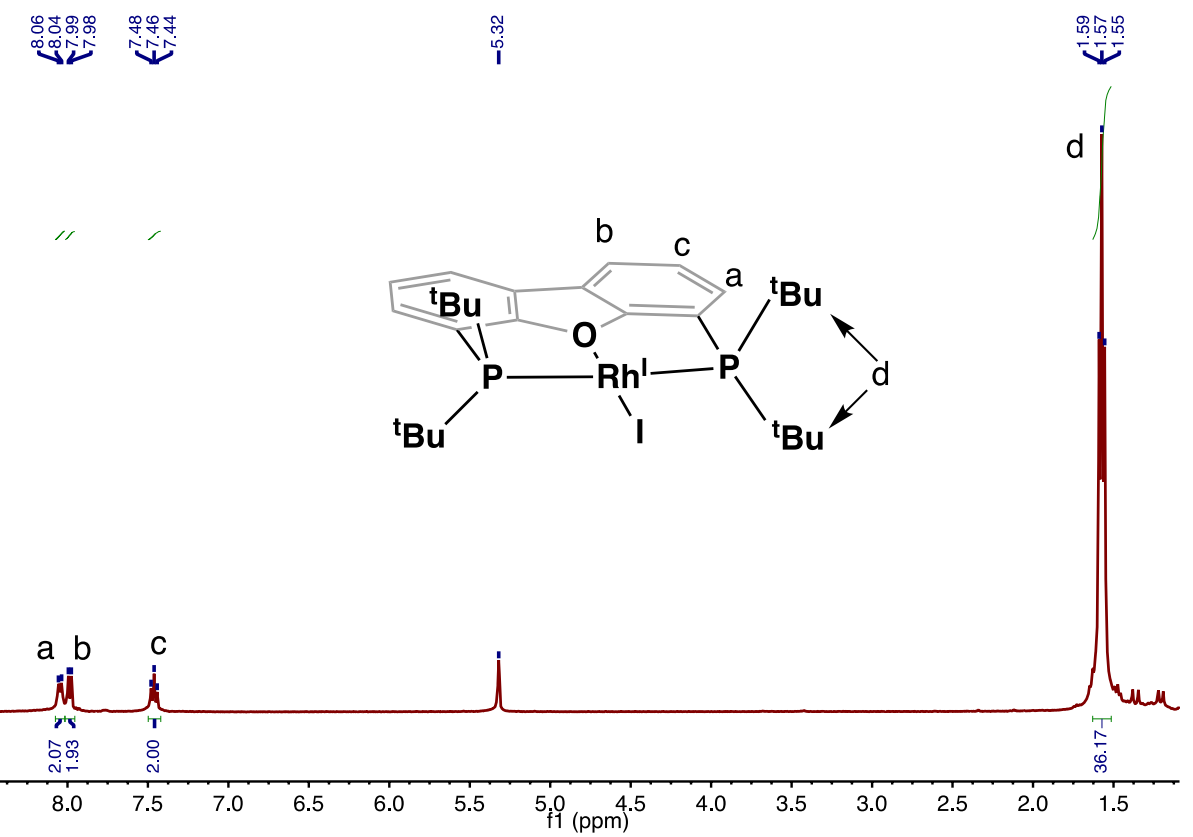

Figure S12: ${ }^{31} \mathrm{P}$ NMR Spectrum of ( $\left.{ }^{\mathrm{t} u P O P}\right) \mathrm{RhI}$ in $\mathrm{CD}_{2} \mathrm{Cl}_{2}$
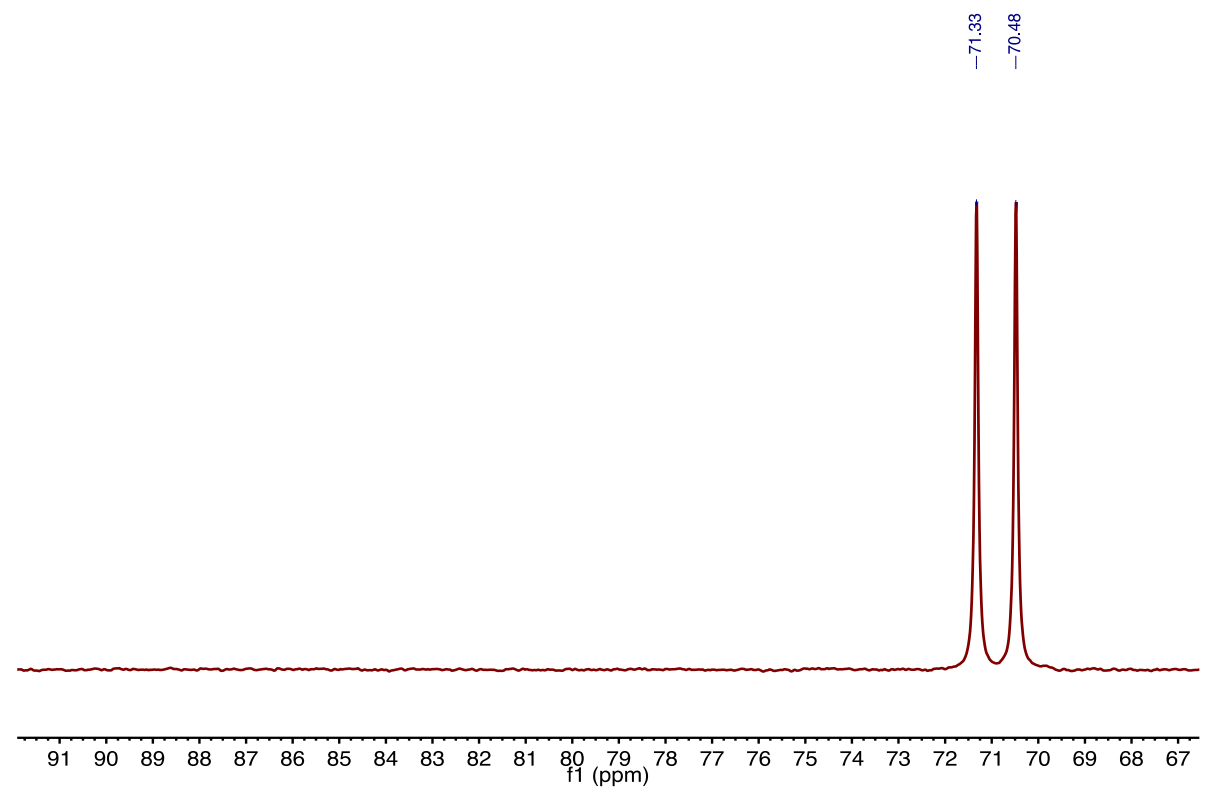
Figure S13: Generation of $[(\mathrm{POP}) \mathrm{RhI}]^{+}$and $\left[(\mathrm{POP}) \mathrm{RhCH}_{2}\right]^{+}$from Redox Cascade Activation of $\mathrm{CH}_{2} \mathrm{Cl}_{2}$ by (POP)RhI.

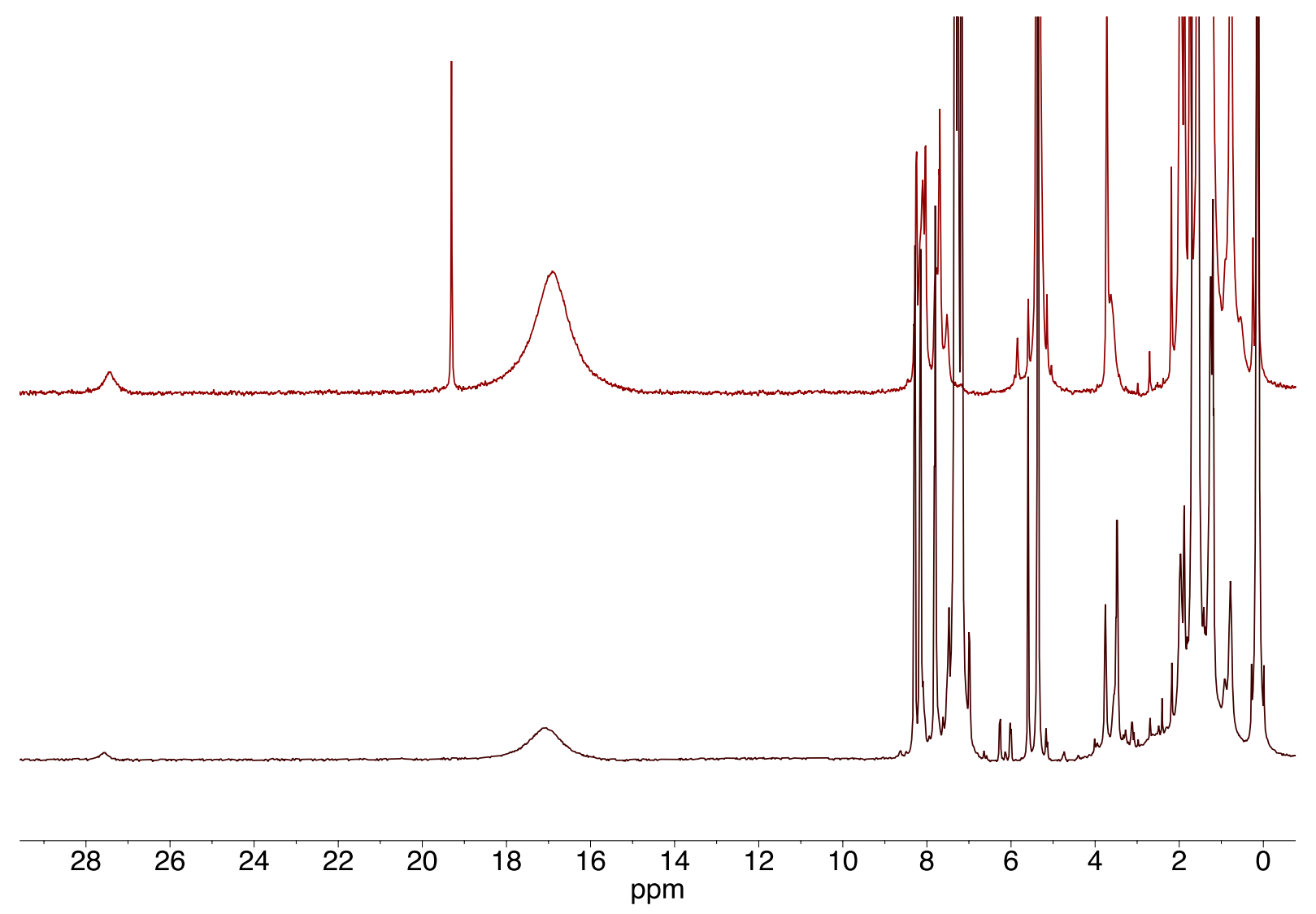

Comparison of the spectra of redox-cascade activation products (from (POP)RhI, $\mathrm{KB}\left(\mathrm{C}_{6} \mathrm{~F}_{5}\right)_{4}$, and $\mathrm{CH}_{2} \mathrm{Cl}_{2}$; top) with spectra of [(POP)RhI ${ }^{+}$prepared independently by oxidation of (POP)RhI with $\left[\mathrm{CPh}_{3}\right]\left[\mathrm{B}\left(\mathrm{C}_{6} \mathrm{~F}_{5}\right)_{4}\right]$ in $\mathrm{CD}_{2} \mathrm{Cl}_{2}$ (bottom). 
Figure S14: ${ }^{1} \mathrm{H}$ and ${ }^{31} \mathrm{P}\left\{{ }^{1} \mathrm{H}\right\}$ (inset) spectra of $[(\mathrm{POP}) \mathrm{Rh}(\mathrm{CHCl})]^{+}$.

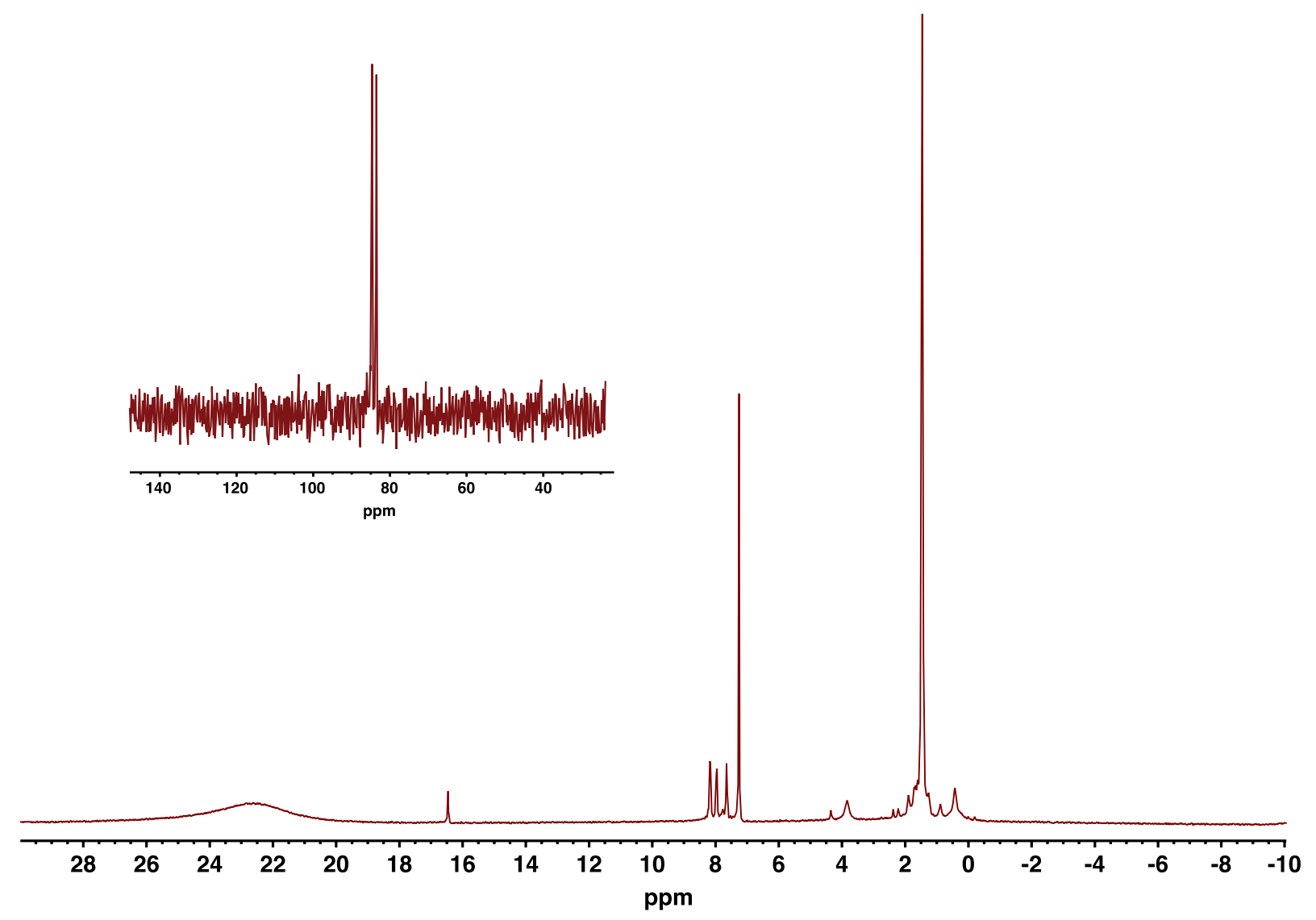

Broad resonances at $23 \mathrm{ppm}, 3.9 \mathrm{ppm}$ and $0.5 \mathrm{ppm}$ are attributable to [(POP)RhCl$]^{+}$produced from redox cascade activation of $\mathrm{CHCl}_{3}$. 


\section{X-ray Crystallography}

A Bruker KAPPA APEX II CCD diffractometer with $0.71073 \AA$ Mo K $\alpha$ radiation was used for diffraction studies. The detector was placed at a distance of $5.13 \mathrm{~cm}$ from the crystal during the data collection. A series of narrow frames of data were collected with a scan width of $0.5^{\circ}$ in $\omega$ or $\phi$ and an exposure time of $10 \mathrm{~s}$ per frame. The frames were integrated with the Bruker SAINT Software package $^{1}$ using a narrow-frame integration algorithm. The space groups were determined on the basis of systematic absences and intensity statistics. The structures were solved by direct methods and refined by full-matrix least squares on $F^{2}$. All nonhydrogen atoms were refined anisotropically unless otherwise stated. Hydrogen atoms were placed at idealized positions and refined using the riding model. Data collection and cell refinement, data reduction, and absorption correction were performed using Bruker's APEX2 (or APEX3), SAINT, and SADABS programs, respectively. ${ }^{6-8}$ Structural solutions and refinements were completed using SHELXL-13, ${ }^{9}$ respectively, as implemented in the OLEX2 (v. 1.2.8) software package. ${ }^{10}$

4,6-bis(di-tert-butylphosphino)dibenzo[b,d]furan (POP). An colorless prism of 4,6-bis(ditert-butylphosphino)dibenzo[b,d]furan of approximate dimensions $0.4 \times 0.2 \times 0.2 \mathrm{~mm}^{3}$ was glued to a glass fiber using Paratone $\mathrm{N}$ oil. The integration of the data using a triclinic unit cell yielded a total of 130681 reflections in the $\theta$ range of 5.504 to $67.456^{\circ}$ of which 10677 were independent with $I \geq 2 \sigma(I)\left(\mathrm{R}_{\text {int }}=0.1112\right)$. All non-hydrogen atoms were located in successive Fourier maps and refined anisotropically. All $\mathrm{H}$ atoms were placed in calculated positions and refined isotropically adapting a riding model with fixed thermal parameters. The final refinement parameters are $R_{1}=0.0522$ and $w R_{2}=0.1047$ for data with $F>4 \sigma(F)$ giving the data to parameter ratio of 36.9. The refinement data for all data are $R_{1}=0.0856$ and $w R_{2}=0.1188$.

$[(\mathbf{P O P}) \mathbf{R h C l}]_{2}\left(\boldsymbol{\mu}^{2}-\mathbf{K}\left[\mathbf{B}\left(\mathbf{C}_{6} \mathbf{F}_{5}\right)_{4}\right)\right)_{2}$. An orange rectangular prism of (POP)RhCl $\cdot \mathrm{K}\left[\mathrm{B}\left(\mathrm{C}_{6} \mathrm{~F}_{5}\right)_{4}\right] \cdot \mathrm{PhF}$ of approximate dimensions $0.20 \times 0.05 \times 0.05 \mathrm{~mm}^{3}$ was glued to a glass fiber using Paratone $\mathrm{N}$ oil. The integration of the data using a triclinic unit cell yielded a total of 87633 reflections in the $\theta$ range of 1.560 to $28.403^{\circ}$ of which 14363 were independent with $I \geq 2 \sigma(I)\left(\mathrm{R}_{\text {int }}=0.1034\right)$. All non-hydrogen atoms were located in successive Fourier maps and refined anisotropically. The asymmetric unit consists of a half of a strongly interacting (POP) RhCl$\cdot \mathrm{K}\left[\mathrm{B}\left(\mathrm{C}_{6} \mathrm{~F}_{5}\right)_{4}\right] \cdot \mathrm{PhF}$ complex unit on general sites. The associated complex is well ordered. All $\mathrm{H}$ atoms were placed in calculated positions and refined isotropically adapting a riding model with fixed thermal parameters. The final refinement parameters are $R_{1}=0.0440$ and $w R_{2}=0.0734$ for data with $F>$ $4 \sigma(F)$ giving the data to parameter ratio of 18.5 . The refinement data for all data are $R_{l}=0.0804$ and $w R_{2}=0.0837$.

[(POP)RhCl $]_{3}\left[\mathbf{B}\left(\mathbf{C}_{6} \mathbf{F}_{5}\right)_{4}\right]_{2}$. A red rectangular prism of $[(\mathrm{POP}) \mathrm{RhCl}]_{3}\left[\mathrm{~B}\left(\mathrm{C}_{6} \mathrm{~F}_{5}\right)_{4}\right]_{2}$ of approximate dimensions $0.23 \times 0.21 \times 0.18 \mathrm{~mm}^{3}$ was glued to a glass fiber using Paratone $\mathrm{N}$ oil. The detector was placed at a distance of $5.12 \mathrm{~cm}$ from the crystal during the data collection. The integration of the data using a monoclinic unit cell yielded a total of 207560 reflections in the $\theta$ range of 1.965 to $35.011^{\circ}$ of which 29079 were independent with $I \geq 2 \sigma(I)\left(\mathrm{R}_{\mathrm{int}}=0.0767\right)$. All non-hydrogen atoms were located in successive Fourier maps and refined anisotropically. The asymmetric unit consists of a half of the $[(\mathrm{POP}) \mathrm{RhCl}]^{+}$complex cation, a (POP) RhCl molecule, and one

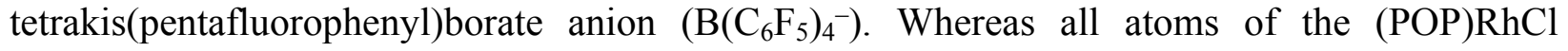
molecule are located on general sites, the cation is situated on a two-fold symmetry axis with the 
$\mathrm{Rh}, \mathrm{Cl}$ and $\mathrm{O}$ atoms of the cation being located on the axis. The $\mathrm{BF}_{20}{ }^{-}$anion is located on general sites. All of them are well separated and well ordered. All $\mathrm{H}$ atoms were placed in calculated positions and refined isotropically adapting a riding model with fixed thermal parameters. The final refinement parameters are $R_{1}=0.0564$ and $w R_{2}=0.1035$ for data with $F>4 \sigma(F)$ giving the data to parameter ratio of 34 . The refinement data for all data are $R_{1}=0.0921$ and $w R_{2}=0.1171$.

[(POP)RhCl] $\left[\mathbf{B}\left(\mathbf{C}_{6} \mathbf{F}_{5}\right)_{4}\right]$. A red rectangular prism of $[(\mathrm{POP}) \mathrm{RhCl}]\left[\mathrm{B}\left(\mathrm{C}_{6} \mathrm{~F}_{5}\right)_{4}\right] \cdot\left(o-\mathrm{C}_{6} \mathrm{H}_{4} \mathrm{~F}_{2}\right)$ of approximate dimensions $0.27 \times 0.23 \times 0.21 \mathrm{~mm}^{3}$ was glued to a glass fiber using Paratone $\mathrm{N}$ oil. The detector was placed at a distance of $5.13 \mathrm{~cm}$ from the crystal during the data collection. The integration of the data using a monoclinic unit cell yielded a total of 207586 reflections in the $\theta$ range of 1.985 to $33.728^{\circ}$ of which 13452 were independent with $I \geq 2 \sigma(I)\left(\mathrm{R}_{\text {int }}=0.0970\right)$. The data were corrected for absorption effects by the multi-scan method (SADABS). The structure was solved and refined by the direct methods using the Bruker SHELXTL (V2017.3-0) Software Package. ${ }^{8}$ All non-hydrogen atoms were located in successive Fourier maps and refined anisotropically. The asymmetric unit consists of a $[(\mathrm{POP}) \mathrm{RhCl}]^{+}$cation, a tetrakis(pentafluorophenyl)borate $\left(\mathrm{B}\left(\mathrm{C}_{6} \mathrm{~F}_{5}\right)_{4}{ }^{-}\right)$anion, and a 1,2-difluorobenzene (dfb) solvent molecule. Both of the ions are well ordered whereas the solvent molecule is highly disordered. Since no satisfactory model could be applied, the SQUEEZE/PLATON program was used to remove their scattering. ${ }^{11}$ The program calculated 245 electrons in a void-space volume of 1012 $\AA^{3}$, and the values are interpreted as diffused electron density resulting from four disordered $\mathrm{dfb}$ molecules in the unit cell. All hydrogen atoms were placed in calculated positions and refined by a riding model with fixed thermal parameters. The final refinement parameters are $R_{1}=0.0448$ and $w R_{2}=0.1217$ for data with $F>4 \sigma(F)$ giving the data to parameter ratio of 38 . The refinement data for all data are $R_{1}=0.0815$ and $w R_{2}=0.1484$. 
Table S1. Crystallographic data for $[(\mathrm{POP}) \mathrm{RhCl}]_{2}\left(\mu^{2}-\mathrm{K}\left[\mathrm{B}\left(\mathrm{C}_{6} \mathrm{~F}_{5}\right)_{4}\right]\right)_{2}$, $\left[(\mathrm{POP}) \mathrm{RhCl}_{3}\left[\mathrm{~B}\left(\mathrm{C}_{6} \mathrm{~F}_{5}\right)_{4}\right]_{2}\right.$, and $[(\mathrm{POP}) \mathrm{RhCl}]\left[\mathrm{B}\left(\mathrm{C}_{6} \mathrm{~F}_{5}\right)_{4}\right]$.

\begin{tabular}{|c|c|c|c|}
\hline compound & {$[(\mathrm{POP}) \mathrm{RhCl}]_{2}\left(\mu^{2}-\mathrm{K}\left[\mathrm{B}\left(\mathrm{C}_{6} \mathrm{~F}_{5}\right)_{4}\right]\right)_{2}$} & {$\left[(\mathrm{POP}) \mathrm{RhCl}_{3}\left[\mathrm{~B}\left(\mathrm{C}_{6} \mathrm{~F}_{5}\right)_{4}\right]_{2}\right.$} & {$[(\mathrm{POP}) \mathrm{RhCl}]\left[\mathrm{B}\left(\mathrm{C}_{6} \mathrm{~F}_{5}\right)_{4}\right]$} \\
\hline Color & Red & Red-orange & Orange \\
\hline $\begin{array}{l}\text { Chemical } \\
\text { Formula }\end{array}$ & $\mathrm{C}_{58} \mathrm{H}_{47} \mathrm{BClF}_{21} \mathrm{KOP}_{2} \mathrm{Rh}$ & $\mathrm{C}_{132} \mathrm{H}_{126} \mathrm{~B}_{2} \mathrm{Cl}_{3} \mathrm{~F}_{40} \mathrm{O}_{3} \mathrm{P}_{6} \mathrm{Rh}_{3}$ & $\mathrm{C}_{58} \mathrm{H}_{46} \mathrm{BClF}_{22} \mathrm{OP}_{2} \mathrm{Rh}$ \\
\hline f. wt., g/mol & 1409.16 & 3142.84 & 1388.06 \\
\hline $\mathbf{T}(\mathbf{K})$ & $100(2)$ & $100(2)$ & $100(2)$ \\
\hline$\lambda(\AA)$ & 0.71073 & 0.71073 & 0.71073 \\
\hline space group & $P-1$ & $P 2 / n$ & $P 2 / n$ \\
\hline$a(\AA)$ & $12.7983(10)$ & $19.606(9)$ & $20.6201(5)$ \\
\hline$b(\AA)$ & $13.7265(11)$ & $10.362(5)$ & $10.1953(2)$ \\
\hline$c(\AA)$ & $17.7061(13)$ & $32.823(14)$ & $28.1058(6)$ \\
\hline$\alpha\left({ }^{\circ}\right)$ & $72.313(2)$ & 90 & 90 \\
\hline$\beta\left(^{\circ}\right)$ & $75.533(2)$ & $97.121(5)$ & $95.629(1)$ \\
\hline$\gamma\left({ }^{\circ}\right)$ & $89.105(2)$ & 90 & 90 \\
\hline$V\left(\AA^{3}\right)$ & $2863.4(4)$ & $6617(5)$ & $5880.1(2)$ \\
\hline$Z$ & 2 & 2 & 4 \\
\hline$D_{\text {calc }}\left(\mathrm{Mg} \mathrm{m}^{-3}\right)$ & 1.634 & 1.578 & 1.568 \\
\hline GoF on $F^{2}$ & 1.024 & 1.056 & 1.056 \\
\hline$\mu\left(\mathrm{mm}^{-1}\right)$ & 0.584 & 0.612 & 0.500 \\
\hline$R 1[I>2 \sigma(I)]^{\mathrm{a}}$ & 0.0440 & 0.0534 & 0.0448 \\
\hline $\begin{array}{c}w R 2[I> \\
2 \sigma(I)]^{\mathrm{b}}\end{array}$ & 0.0734 & 0.1035 & 0.1217 \\
\hline \multicolumn{4}{|c|}{$\left.{ }^{\mathrm{a}} R 1=\sum \| \mathbf{F}_{0}-\left|\mathbf{F}_{\mathrm{c}}\right| / \sum\left|\mathrm{F}_{\mathrm{o}}\right| ;{ }_{w}{ }_{w} R 2=\left\{\sum\left[w\left(F_{o}{ }^{2}-F_{c}{ }^{2}\right)^{2}\right] / \sum w\left(F_{o}{ }^{2}\right)^{2}\right]\right\}^{1 / 2}$} \\
\hline
\end{tabular}


Figure S15. View of crystallographically independent molecules of (POP)RhCl (top) and $[(\mathrm{POP}) \mathrm{RhCl}]^{+}$(bottom).
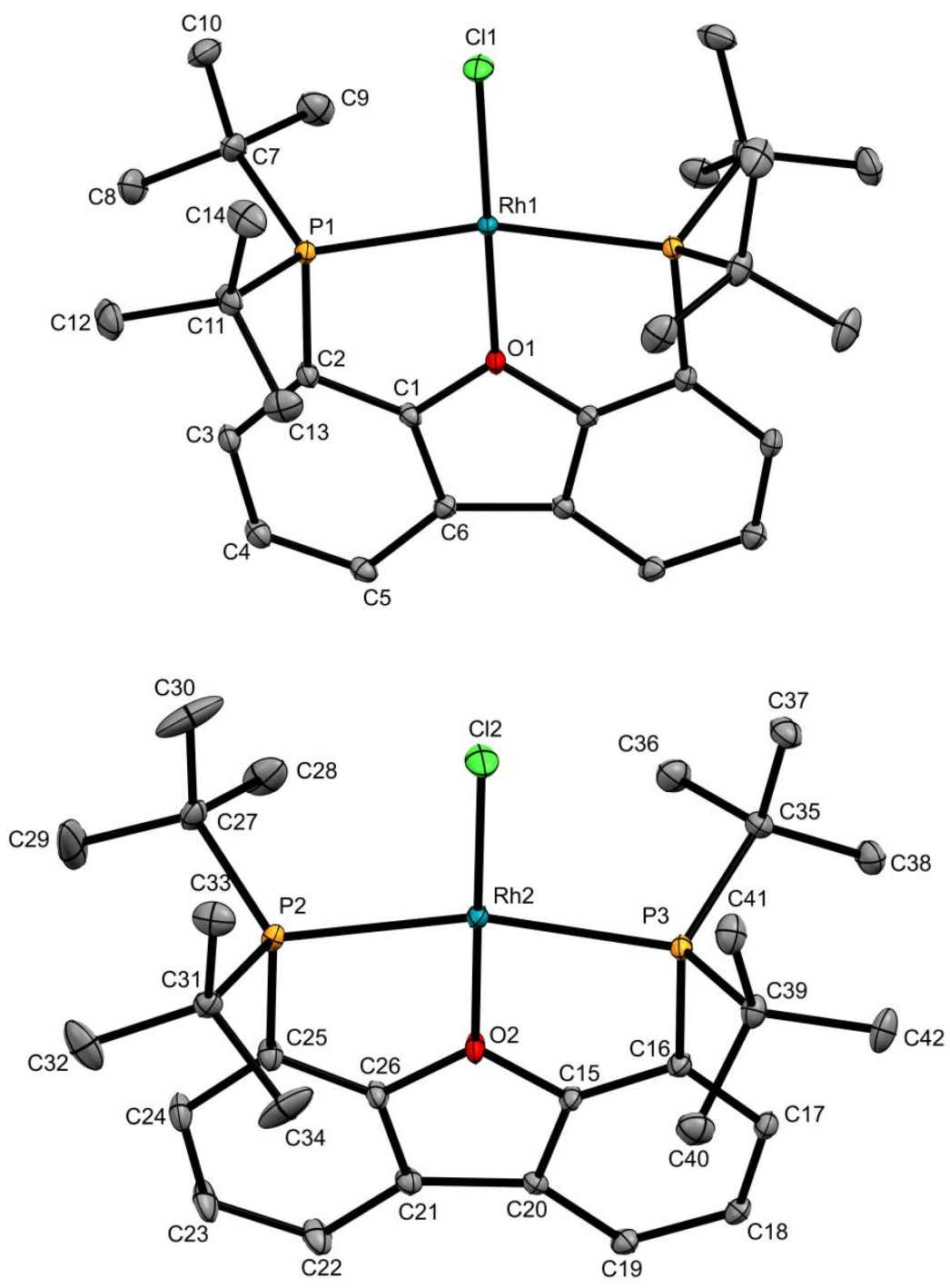

Symmetric equivalents are unlabeled. Hydrogen atoms are omitted, and the thermal parameters are drawn at $50 \%$ probability. 
Table S2. Comparison of Calculated and Experimental Bond Length and Angles for (POP)RhCl and [(POP)RhCl $]^{+}$

\begin{tabular}{c|c|c|c|c|c|}
\multirow{2}{*}{ Metric } & \multicolumn{2}{|c|}{$(\mathrm{POP}) \mathrm{RhCl}$} & \multicolumn{2}{c|}{$[(\mathrm{POP}) \mathrm{RhCl}]^{+}$} \\
\cline { 2 - 6 } & Exp. $^{*}$ & Calc. & Exp. $(1)^{\ddagger}$ & Exp. $(2)^{\dagger}$ & Calc. \\
\hline $\mathrm{Rh}-\mathrm{Cl}(\AA)$ & $2.3056(13)$ & 2.371 & $2.2663(12)$ & $2.2676(5)$ & 2.285 \\
\hline $\mathrm{Rh}-\mathrm{P}_{1}(\AA)$ & $2.3250(11)$ & 2.346 & $2.3979(12)$ & $2.3880(5)$ & 2.412 \\
\hline $\mathrm{Rh}-\mathrm{P}_{2}(\AA)$ & - & 2.347 & $2.4006(12)$ & $2.4057(5)$ & 2.420 \\
\hline $\mathrm{Rh}-\mathrm{O}(\AA)$ & $1.999(2)$ & 2.046 & $1.990(2)$ & $1.9860(14)$ & 2.017 \\
\hline $\mathrm{C}_{\mathrm{Ar} 1}-\mathrm{O}(\AA)$ & $1.373(2)$ & 1.359 & $1.386(3)$ & $1.382(2)$ & 1.375 \\
\hline $\mathrm{C}_{\mathrm{Ar} 2}-\mathrm{O}(\AA)$ & - & 1.359 & $1.378(3)$ & $1.390(2)$ & 1.375 \\
\hline $\mathrm{C}_{\mathrm{Ar}}-\mathrm{P}_{1}(\AA)$ & $1.867(2)$ & 1.859 & $1.848(2)$ & $1.840(2)$ & 1.849 \\
\hline $\mathrm{C}_{\mathrm{Ar}}-\mathrm{P}_{2}(\AA)$ & - & 1.859 & $1.857(2)$ & $1.841(2)$ & 1.850 \\
\hline $\mathrm{P}_{1}-\mathrm{Rh}-\mathrm{Cl}\left(^{\circ}\right)$ & $99.119(15)$ & 100.16 & $98.87(2)$ & $98.72(2)$ & 99.50 \\
\hline $\mathrm{P}_{2}-\mathrm{Rh}-\mathrm{Cl}\left(^{\circ}\right)$ & - & 100.21 & $99.55(2)$ & $100.02(2)$ & 100.37 \\
\hline $\mathrm{P}_{1}-\mathrm{Rh}-\mathrm{P}_{2}\left(^{\circ}\right)$ & $161.76(3)$ & 159.62 & $161.58(2)$ & $161.25(2)$ & 160.11 \\
\hline $\mathrm{P}_{1}-\mathrm{Rh}-\mathrm{O}\left(^{\circ}\right)$ & $80.881(15)$ & 79.82 & $80.84(4)$ & $80.76(4)$ & 80.15 \\
\hline $\mathrm{P}_{2}-\mathrm{Rh}-\mathrm{O}\left(^{\circ}\right)$ & - & 79.82 & $80.77(4)$ & $80.49(4)$ & 79.97 \\
\hline $\mathrm{O}_{-}-\mathrm{Rh}-\mathrm{Cl}\left(^{\circ}\right)$ & 180 & 179.84 & $176.94(5)$ & $177.92(5)$ & 178.85 \\
\hline
\end{tabular}

* From the $\mathrm{Rh}^{\mathrm{I}}$ component of $\left[((\mathrm{POP}) \mathrm{RhCl})_{3}\left(\mathrm{~B}_{(}\left(\mathrm{C}_{6} \mathrm{~F}_{5}\right)_{4}\right)_{2}\right]$ - Half of the molecule is in the asymmetric unit, thus the molecule has a crystallographic plane of symmetry and the $\mathrm{O}-\mathrm{Rh}-\mathrm{Cl}$ angle is imposed by symmetry.

${ }^{*}$ From the $\mathrm{Rh}^{\mathrm{II}}$ component of $\left[((\mathrm{POP}) \mathrm{RhCl})_{3}\left(\mathrm{~B}\left(\mathrm{C}_{6} \mathrm{~F}_{5}\right)_{4}\right)_{2}\right]$

${ }^{\dagger}$ From $\left[((\mathrm{POP}) \mathrm{RhCl})\left(\mathrm{B}\left(\mathrm{C}_{6} \mathrm{~F}_{5}\right)_{4}\right)\right]$ 
Table S3. Calculated $\Delta G_{\text {reaction }}$ and Formal Redox Potentials for Proposed Intermediates

Redox, Rearrangement, and Addition Reactions

Free Energy

$(\Delta G, \mathrm{kcal} / \mathrm{mol})$

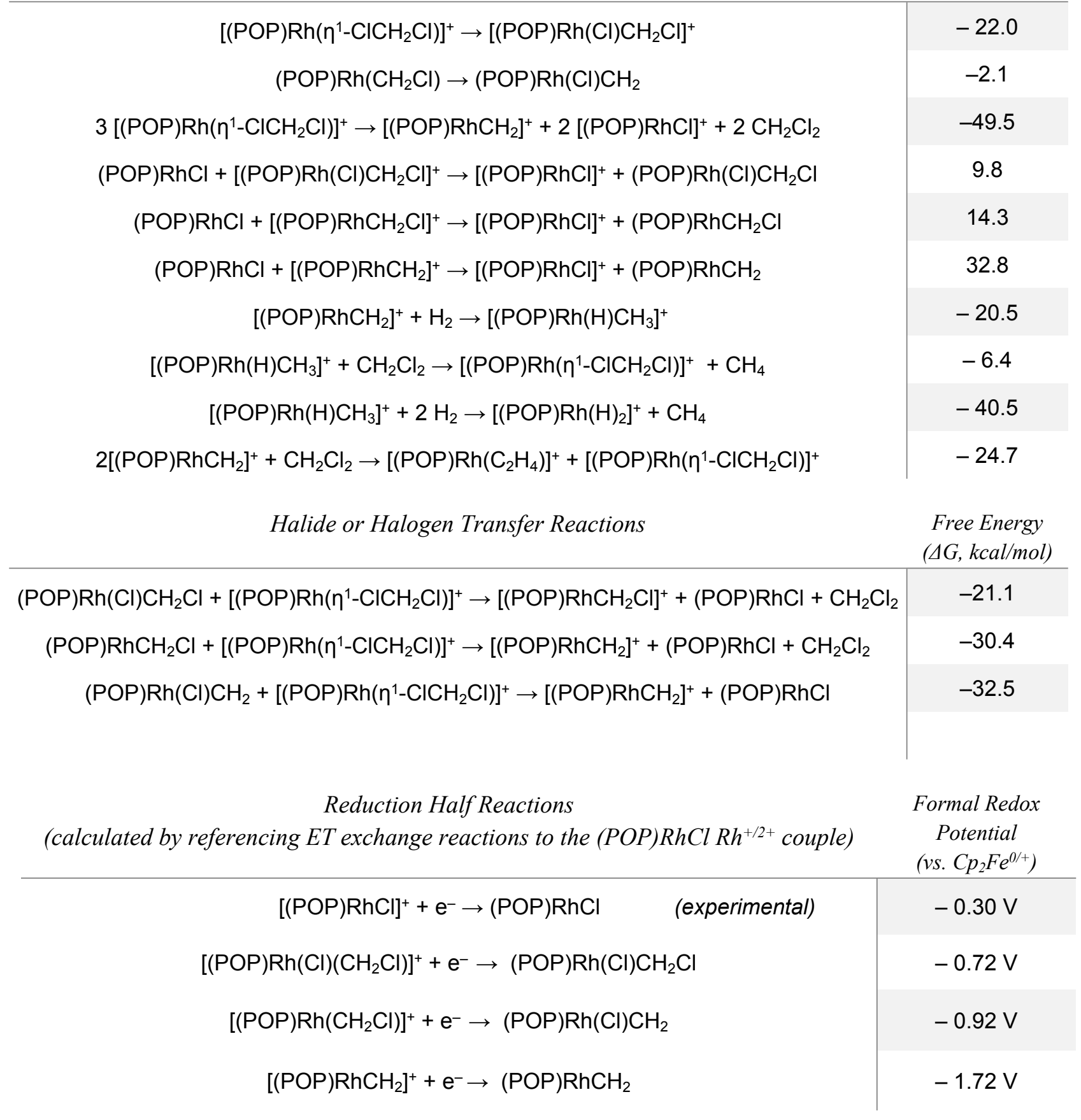

Reduction potentials were calculated from the absolute free energies of the redox partners - free energies of reaction were calculated for electron transfer between the species of interest (e.g. [(POP) $\left.\left.\mathrm{RhCH}_{2}\right]^{+}\right)$and $(\mathrm{POP}) \mathrm{RhCl}$ and the resulting free energy of reaction was converted to a redox potential using the measured (POP)RhCl/[(POP)RhCl $]^{+}$ redox couple and $\Delta \mathrm{G}=-\mathrm{n} F \mathrm{E}^{\circ}$. 
Figure S16. Relaxed Surface Scan of methylidene rotation in $\left[(\mathrm{POP}) \mathrm{Rh}=\mathrm{CH}_{2}\right]^{+}$

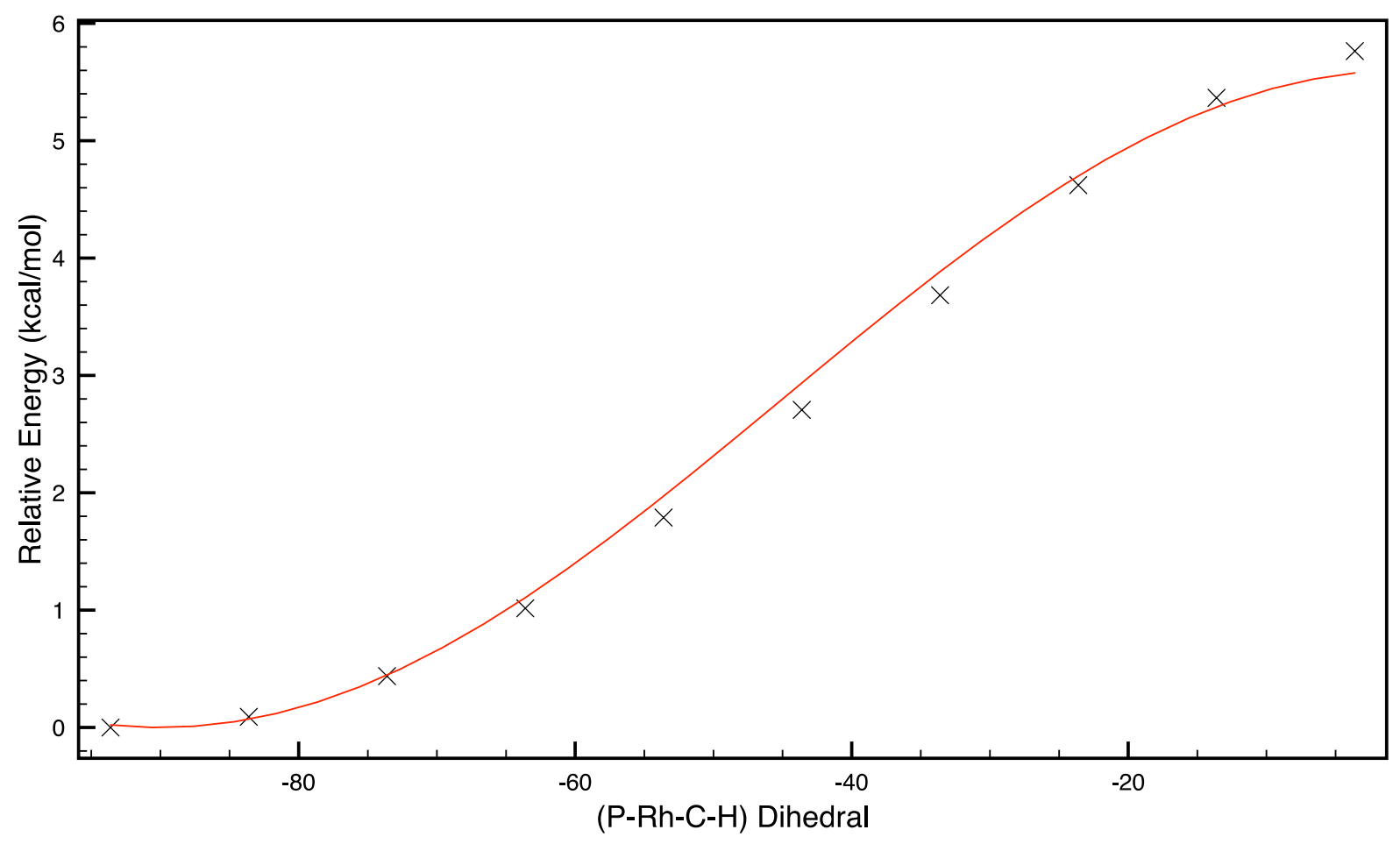

The scan has been plotted as indicating the stability of the perpendicular binding mode and modest barrier to rotation $(5.8 \mathrm{kcal} / \mathrm{mol})$. A simple sinusoidal fit of the $\mathrm{D}(\mathrm{P}-\mathrm{Rh}-\mathrm{C}-\mathrm{H})$ dihedral angle $\left(\boldsymbol{f}(\boldsymbol{x})=\mathbf{2 . 8 0} * \cos \left(\boldsymbol{D} * \frac{\boldsymbol{\pi}}{\mathbf{3 6 0}}\right)+2.80\right)$ is presented in red as a guide to the eye. 
Table S4. Pressure Corrected Boiling Points for Selected Solvents and Reagents

\begin{tabular}{|c|c|c|c|c|c|}
\multicolumn{1}{c|}{ Solvent } & $\begin{array}{c}\Delta \mathrm{H}_{\mathrm{vap}} \\
(\mathrm{kJ} / \mathrm{mol})\end{array}$ & $\begin{array}{c}\mathrm{T}_{\text {boil }} \\
\left({ }^{\circ} \mathrm{C}, 1 \mathrm{~atm}\right)\end{array}$ & $\begin{array}{c}\mathrm{T}_{\text {boil }} \\
(\mathrm{K}, 1 \mathrm{~atm})\end{array}$ & $\begin{array}{c}\mathrm{T}_{\text {boil }} \\
\left({ }^{\circ} \mathrm{C}, 0.77 \mathrm{~atm}\right)\end{array}$ & $\begin{array}{c}\mathrm{T}_{\text {boil }} \\
(\mathrm{K}, 0.77 \mathrm{~atm})\end{array}$ \\
\hline dichloromethane & 29.2 & 39.6 & 312.75 & 32 & 305.5 \\
\hline diethyl ether & 28.1 & 34.6 & 307.75 & 27 & 300.4 \\
\hline THF & 30.8 & 66 & 339.15 & 58 & 331.0 \\
\hline fluorobenzene & 31.2 & 84.5 & 357.65 & 76 & 348.8 \\
\hline benzene & 33.83 & 80.1 & 353.25 & 72 & 345.2 \\
\hline toluene & 33.5 & 111 & 384.15 & 101 & 374.6 \\
\hline hexane & 31.52 & 69 & 342.15 & 61 & 334.1 \\
\hline pentane & 26.42 & 36 & 309.15 & 28 & 301.3 \\
\hline water & 43.99 & 100 & 373.15 & 93 & 366.2 \\
\hline ethanol & 40.5 & 78.37 & 351.52 & 72 & 344.9 \\
\hline methanol & 35.4 & 64.7 & 337.85 & 58 & 330.8 \\
\hline 1,2 -dichloroethane & 34.8 & 84 & 357.15 & 76 & 349.2 \\
\hline isopropanol & 39.8 & 82.6 & 355.75 & 76 & 348.8 \\
\hline acetone & 31.1 & 56.05 & 329.2 & 48 & 321.6 \\
\hline DMSO & 48.6 & 189 & 462.15 & 179 & 452.6 \\
\hline DMF & 56.7 & 153 & 426.15 & 146 & 419.1 \\
\hline MTBE & 29.6 & 55.2 & 328.35 & 47 & 320.4 \\
\hline heptane & 36.57 & 98.4 & 371.55 & 90 & 363.3 \\
\hline octane & 41.56 & 125.5 & 398.65 & 117 & 390.3 \\
\hline chloroform & 30.9 & 61.15 & 334.3 & 53 & 326.4 \\
\hline acetonitrile & 33.3 & 81.7 & 354.85 & 73 & 346.6 \\
\hline o-difluorobenzene & 32.2 & 92 & 365.15 & 83 & 356.2 \\
\hline & & & & & \\
\hline
\end{tabular}




\section{References.}

(1) Herde, J. L.; Lambert, J. C.; Senoff, C. V. Inorg. Synth. 1974, 15, 18.

(2) Bihlmeier, A.; Gonsior, M.; Raabe, I.; Trapp, N.; Krossing, I. Chem. - A Eur. J. 2004, 10 (20), 5041.

(3) Krossing, I.; Reisinger, A. Coord. Chem. Rev. 2006, 250 (21-22), 2721.

(4) Esteruelas, M. A.; Oliván, M.; Vélez, A. Inorg. Chem. 2013, 52 (9), 5339.

(5) Fulmer, G. R.; Miller, A. J. M.; Sherden, N. H.; Gottlieb, H. E.; Nudelman, A.; Stoltz, B. M.; Bercaw, J. E.; Goldberg, K. I. Organometallics 2010, 29 (9), 2176.

(6) Bruker. Apex II. 2009, p Bruker AXS Inc., Madison, Wisconsin, USA.

(7) Sheldrick, G. M. SADABS, Programs for Scaling and Absorption Correction of Area Detector Data. 1997, p University of Göttingen: Göttingen, Germany.

(8) Bruker AXS, Inc.: Madison, WI 2017,.

(9) Sheldrick, G. M. Acta Crystallogr. Sect. A Found. Crystallogr. 2008, 64 (1), 112.

(10) Dolomanov, O. V.; Bourhis, L. J.; Gildea, R. J.; Howard, J. A. K.; Puschmann, H. J. Appl. Crystallogr. 2009, 42 (2), 339.

(11) Spek, A. L. Acta Crystallogr. Sect. C Struct. Chem. 2015, 71 (1), 9.

(12) Frisch, M. J.; Trucks, G. W.; Schlegel, H. B.; Scuseria, G. E.; Robb, M. A.; Cheeseman, J. R.; Scalmani, G.; Barone, V.; Petersson, G. A.; Nakatsuji, H.; Li, X.; Caricato, M.;

Marenich, A. V; Bloino, J.; Janesko, B. G.; Gomperts, R.; Mennucci, B.; Hratchian, H. P.; Ortiz, J. V; Izmaylov, A. F.; Sonnenberg, J. L.; Williams-Young, D.; Ding, F.; Lipparini, F.; Egidi, F.; Goings, J.; Peng, B.; Petrone, A.; Henderson, T.; Ranasinghe, D.;

Zakrzewski, V. G.; Gao, J.; Rega, N.; Zheng, G.; Liang, W.; Hada, M.; Ehara, M.; Toyota, K.; Fukuda, R.; Hasegawa, J.; Ishida, M.; Nakajima, T.; Honda, Y.; Kitao, O.; Nakai, H.; Vreven, T.; Throssell, K.; Montgomery Jr., J. A.; Peralta, J. E.; Ogliaro, F.; Bearpark, M. J.; Heyd, J. J.; Brothers, E. N.; Kudin, K. N.; Staroverov, V. N.; Keith, T. A.; Kobayashi, R.; Normand, J.; Raghavachari, K.; Rendell, A. P.; Burant, J. C.; Iyengar, S. S.; Tomasi, J.; Cossi, M.; Millam, J. M.; Klene, M.; Adamo, C.; Cammi, R.; Ochterski, J. W.; Martin, R. L.; Morokuma, K.; Farkas, O.; Foresman, J. B.; Fox, D. J. Gaussian, Inc.: Wallingford CT 2016,

(13) Zhao, Y.; Truhlar, D. G. J. Chem. Phys. 2006, 125 (19).

(14) Zhao, Y.; Truhlar, D. G. Theor. Chem. Acc. 2008, 120 (1-3), 215.

(15) Peverati, R.; Truhlar, D. G. Phys. Chem. Chem. Phys. 2012, 14 (38), 13171.

(16) Becke, A. D. J. Chem. Phys. 1993, 98 (7), 5648.

(17) Weigend, F.; Ahlrichs, R. Phys. Chem. Chem. Phys. 2005, 7 (18), 3297. 